Itinéraires Itinéraires

Littérature, textes, cultures

2015-2 | 2016

Stumbling blocks. Entraves et obstacles aux circulations

\title{
Pippi Longstocking, Juvenile Delinquent? Hachette, Self-Censorship and the Moral Reconstruction of Postwar France
}

Fifi Brindacier, blouson noir? Hachette, auto-censure et reconstruction morale dans la France de l'après-guerre

\section{Sophie Heywood}

\section{(2) OpenEdition}

\section{Journals}

Electronic version

URL: http://journals.openedition.org/itineraires/2903

DOI: 10.4000/itineraires.2903

ISSN: 2427-920X

\section{Publisher}

Pléiade

\section{Electronic reference}

Sophie Heywood, « Pippi Longstocking, Juvenile Delinquent? Hachette, Self-Censorship and the Moral Reconstruction of Postwar France », Itinéraires [Online], 2015-2 | 2016, Online since 15 February 2016, connection on 20 April 2019. URL : http://journals.openedition.org/itineraires/2903 ; DOI : 10.4000/ itineraires. 2903

This text was automatically generated on 20 April 2019.

\section{c)}

Itinéraires est mis à disposition selon les termes de la licence Creative Commons Attribution - Pas d'Utilisation Commerciale - Pas de Modification 4.0 International. 


\title{
Pippi Longstocking, Juvenile Delinquent? Hachette, Self- Censorship and the Moral Reconstruction of Postwar France
}

\author{
Fifi Brindacier, blouson noir? Hachette, auto-censure et reconstruction morale \\ dans la France de l'après-guerre
}

Sophie Heywood

1 Why was Fifi Brindacier, the French version of the Swedish Pippi Longstocking series, only two-thirds the length of the original? How was it that the Famous Five series by the notoriously conservative English author Enid Blyton raised moral concerns amongst the reading committee at her French publisher? What did the reader for the publisher Hachette mean when he rejected Angry Waters, by the popular American author for children, Walt Morey, because "the book was hardly suitable for 'our' children"? ${ }^{1}$

All these examples date from the 1950s and 1960s, a period described at the time by the journalist Herbert Lottman (1966: 5709) as characterised by "incredibly severe" censorship and surveillance of publications for the young. This article examines the blockages to the publication of children's literature caused by the intellectual climate of the postwar era, through a case study of the editorial policy of Hachette, the largest publisher for children at the time. These years witnessed heightened tensions surrounding the social and humanitarian responsibilities of literature (Sapiro 1999). Writers were blamed for having created a culture of defeatism, and collaborationist authors were punished harshly in the postwar purges. In the case of children's books, the discourse on responsibility was made more urgent by the assumption that children were easily influenced by their reading material, and by the centrality of the young to the discourse on the moral reconstruction of France (Jobs 2007). As the politician and education reformer Gustave Monod (1954:2) put it: "to think of the future is to think of our children's future." ${ }^{2}$ These concerns led to the expansion of associations and 
publications dedicated to protecting children and promoting "good" reading matter for them, ${ }^{3}$ and to the 1949 law regulating publications for children, which banned the depiction of crime, debauchery and violence that might demoralise young readers.

The stated aim of the 1949 law and the associated campaigns was to prevent the spread of American and other foreign comics, which had "invaded" the French market in the 1930s. An unlikely alliance between the Communists and the Catholics had spearheaded the child protection movement, as pre-existing fears about mass culture were overlaid with Cold War concerns and the discourse on the responsibility of literature. For the Communists, the campaign focused on denouncing American cultural imperialism, while Jean-Yves Mollier has recently demonstrated that the 1949 law also forms part of a much longer history of Catholic campaigns to regulate book production and reading. He argues that it represented a victory for the Church over the anti-censorship laws introduced in the Third Republic (Mollier 2014). Research into the applications of the 1949 law has focused chiefly on the censorship of comics, and its later use against adult pornography (Crépin and Groensteen 1999, Jobs 2007: 232-68). ${ }^{4}$ Still, Jean-Pierre Rioux reminds us not to lose sight of the fact that the campaigns and the law were all aimed specifically at children: "the framework of the 1949 law was so exceptionally wide that it must not simply be understood as a straightforward history of censorship. For patriotic reasonswhich the war had served to underline-people firmly believed that the nation owed its children the strictest protection, to ensure a happier future. ${ }^{5}$ And the guidance issued to publishers by the 1949 law commission was very clear that "even if their material is purely recreational, they [publishers] play a part in the education of their young readers. They share educational responsibilities with the family, the school, the teaching profession, the cinema and the press." was never used against book publishers, it furnished them with the legal framework and guidelines on their role to which the majority of presses strove to conform. ${ }^{7}$ Certainly all books for children from the 1950s onwards in France have stated in their front matter that they conform to the 1949 law.

Following Rioux's argument that the 1949 law was part of the wider concern for child protection and juvenile delinquency in the postwar era, this article focuses on one of the law's primary functions, to protect the nation's children from pernicious foreign influences. For this reason, we must explore the impact on translations and processes of cultural transfer in children's books. As Gideon Toury writes, norms in translation are socially constructed "instructions" that specify what is forbidden, as well as what is permitted. If, as in the case of the 1949 law commission's guidelines to publishers, such norms are verbalised, they indicate a particular significance to the culture (Toury 2012: 63-64). What were the norms generated by the 1949 law and the intellectual climate of the era? How were such norms affected by different constructions of childhood in France and internationally? To answer these questions, Hachette provides an excellent case study, not only because it was the largest publisher for children (Piquard 2004: 41-50), but also because the great success of its children's series depended on imported fiction. Using readers' reports and editorial correspondence preserved in the Hachette archives ${ }^{8}$ this article will examine how and to what extent editorial mediations were shaped by the 1949 law on publications for children with its attendant discourse on the perils of foreign imports for children's education, and how national concerns for future citizens and Hachette's educational ethos were balanced with commercial imperatives. 
Hachette launched a large-scale modernisation project for its children's series in the late 1950s (Bauland 1997: 116-21, Mistler 1964: 376-85). By the end of the decade nearly a third of the population was under twenty. A series of long-awaited reforms in 1959 extended the obligatory school age from 14 to 16, and widened access to secondary schooling. Hachette therefore concentrated on investing in its main children's series, the Bibliothèque Rose and the Bibliothèque Verte. Both management and production were rationalised. The books were now printed on new rotary presses, which required at least 30,000 copies per run in order to achieve their brightly coloured covers and illustrations at the right price. As Louis Mirman, the head of series in the new Children's Department, explained in an interview in 1956: "our large print runs have a drawback-they restrict us to safe choices." In practice this meant that the percentage of modern, imported titles was greatly increased, with the focus on popular Anglo-American series literature, notably works by Enid Blyton and the Nancy Drew series from the Stratemeyer syndicate. The proportion of foreign titles in the Bibliothèque Rose in the 1940s had been only $10 \%-$ and mostly classics such as Andersen. By the late 1950s the list was almost 50\% modern translations. Such enormous print runs and the high percentage of imported titles also entailed greater moral responsibility. The new Department established a careful system for the rigorous examination and self-censorship of all texts to ensure they were suitable for the French market. It is the traces of this system, left behind in the deliberations of the readers' reports, that I use to examine the organising principles behind the selfcensorship process.

\section{Detecting Delinquency in Children's Books}

6 The 1949 law stated that publications destined for a young audience must not "portray in a favourable light banditry, lying, stealing, laziness, cowardice, hatred, debauchery or any acts that are classed as crimes or misdemeanours." ${ }^{10}$ The fear that depictions of crime in American comics conditioned children to see it as acceptable was common to morality campaigns across the globe (Lent 2009). This discourse constructed children as a particularly vulnerable readership, because of their mimetic instinct, and lack of capacity for critical reasoning. As the leading critic at the time, Marc Soriano put it: "he lives what he reads" ${ }^{11}$ (Soriano 1966: 88-89). The Ministère de l'Éducation Nationale calculated in 1948 that $88 \%$ of juvenile delinquents were avid comic readers (Crépin 2001: 227-29). This concern extended to children's books. Mirman's strategy for Hachette's children's series was to capitalise on the popular thirst for the newly expanding genre of the detective story for children. Blyton had established the formula, and French authors such as PaulJacques Bonzon and Michel Bayard followed it with success. ${ }^{12}$ The readers' reports in the Hachette archives indicate that the skill lay in writing about crime detection whilst drawing what one reader called "a discreet veil"13 over the crime itself. Blyton was the past master at this. She saw her writing as a bulwark against American popular culture, particularly comics, and was very strict when writing material suitable for children: "no murders. No ghosts. No horror. No blood" (Rudd 2008: 262). When Georges Chaulet presented to Hachette his Fantômette series, featuring a female superhero who solves crimes, he recalled how "Monsieur Mirman told me: there are conditions. You must modify your text: there are to be no murders, no blood, and the villains must speak in a refined language without cursing." ${ }^{14}$ As one reader asked when faced with a manuscript by Bonzon that described an attempted murder, was such a book really suitable for the 
children's series, where "the young reader is used to finding thieves or bandits who are stupid rather than villainous, and plots that are rather 'saccharine'?"15

The norm that was perhaps trickier to define and enforce was what was unacceptable child behaviour. Fears of juvenile delinquency were strong. The comics debate and the blousons noirs' (rockers) love of American teen culture had furthered the perception that this was the result of a foreign perversion of the French youth. American texts representing juvenile delinquency were deemed unsuitable for the French market by the Hachette readers. As one of the reader's reports on Angry Waters (1969) by Walt Morey (best known for his Gentle Ben books) put it, Hachette was far from being alone in this policy: "the subject of this novel is juvenile delinquency; a rather delicate subject that does not appear to have featured in series for readers aged between 10-12 years, at least not in France." ${ }^{16}$ Morey's brief text for adolescent readers was a serious tale of a young gang member given a second chance when he is sent out to work on a farm. However, while it in no way depicted delinquency "in a favourable light," the manuscript was rejected, with a clear eye to protecting the nation's young: it was deemed to be "hardly suitable for 'our youth." ${ }^{17}$ By way of contrast, the French author René Guillot's Red kid de l'Arizona (1959), an adventure story set in the Wild West also caused problems, but the tenor of discussion between the readers was markedly different. ${ }^{18}$ The committee was reticent, with one suggesting the book was a little too "hard" for children, and a second recommended that the characters' violent behaviour should be softened. They all agreed however that it would be awful to lose a manuscript from this well-loved author to another publisher. Thus the French book made it into press, while the American text was rejected. Similar concerns were raised regarding Guillot's later novel, Le grand Marc et les aigles noirs (1965), about a group of teenagers from deprived backgrounds who find redemption together by setting up a youth camp in a former medieval fort. ${ }^{19}$ One of the reports explained that caution was necessary as the heroes of the book were "blousons noirs" (rockers). He concluded that although there was no danger of real teenage delinquents reading the book, it would teach other boys about them. Nevertheless, the book was deemed sufficiently general to be "healthy"; in other words, it would not demoralise readers. It is interesting that he draws this distinction in potential readership: while comics were perceived to be the reading material of choice for the juvenile delinquent, books could be treated differently. The reader's interpretation of this norm was clearly freer than the treatment Morey's Angry Waters received, but both examples are revelatory of the thinking that underpinned the reading process. All treated the subject of youthful criminality as difficult and requiring careful censorship. Commercially however, losing a popular, respected French author was considered to be more dangerous than the potential criticism of his subject matter.

8 By extension, modes of behaviours such as lying or moral ambiguity were often condemned, even compared to that of "blouson noirs." As one reader at Hachette explained, when talking about Fifi Brindacier, the French version of the Swedish heroine Pippi Longstocking:

the character of Fifi does not conform to the norms of the Bibliothèque Rose. Fifi is a liar from the beginning to the end of these two books. [...] And what is her ambition in life? 'To become a ferocious pirate and spread death and terror in my wake.' This Fifi seems to be the little sister of our blousons noirs. ${ }^{20}$

The English author Ursula Moray Williams's Johnnie Tigerskin (1964) caused similar problems. The story featured a young girl who is neglected by her parents and resorts to 
making up fantastical stories to compensate for her loneliness. She tells "beautiful lies" that the children wish were true. ${ }^{21}$ But eventually her lies escalate into thieving and accidental malice. One of the Hachette readers picked up on this problem: "there is however one problem: the little girl to whom lying comes as naturally as breathing and who is the novel's heroine; a sympathetic heroine. Is this a good example for children who just want to give free reign to their imaginations?"22 In both cases the readers worried that forms of imaginative play such as telling tall tales or make-believe games about being a pirate risked blurring children's understanding of the distinctions between good and bad behaviour. There was a similar suspicion of fantasy in the 1949 law committee guidelines: "while allowing for dreams, for fantasy and adventure, avoid excessively implausible tales and disconcerting mysteries, or at least avoid presenting them in such a way that risks confusing the real and the imagined, and disorientating the reader." ${ }^{23}$ Encouraging children to identify with imaginative but unruly protagonists risked encouraging delinquent behaviour.

\section{The Child, the Family and the State}

Realism in children's books was crucial, not just for avoiding moral ambiguity, but also for defining the relationship of the child to its family and society, as the guidelines to publishers made clear: "except where nature of the story does not permit it, set the characters within their familial, professional or social context." ${ }^{24}$ It is striking how the readers at Hachette were concerned that the child be represented within a clear system of authority structures. They were particularly alert to how the individual child behaved with respect to the family and institutions of the state. Hachette's books ought to inculcate a proper respect for these institutions. This placed the Hachette series in tension with new currents in writing from abroad, which sought to write from the child's point of view, freed from the adult authoritarian voice (Ewers 1998: 472-77). Inspired by the progressive education movement, many modern authors took a liberationist as opposed to a protectionist stance on childhood. This supposed "child-centred" approach laid emphasis on freedom, independence from parents and adults, and the joys of roaming the countryside, and was garnering acclaim in much of Northern Europe and the States in the postwar era.

11 The case of the most famous example of postwar child-centred literature, Swedish author Astrid Lindgren's Pippi Longstocking trilogy (1945-48), illustrates how this approach clashed with French ideas on childhood. The child lives on her own, for her mother is dead and her father is lost at sea-probably king of the cannibals now, Pippi surmises. Endowed with superhuman strength ("in all the world there was no policeman as strong as she" ${ }^{25}$ ) and a large bag of gold, she can do as she pleases. Her adventures range from the sweet to the nonsensical, punctuated by Pippi's many tall tales. She evades all attempts to make her conform to the usual path of childhood, including sending her to an orphanage, attending school, or even going to bed at night. Pippi, an extreme example of such literature to be sure, generated unease at the modernised Children's Department at Hachette. The first translation of the trilogy (reduced to two books published in 1951-53) did not differ greatly from the source text. However, when reprinted with a much larger print run (from 10,000 per volume to 50,000 in 1962-63) under Mirman, it was drastically cut-as the quotation above made clear, the character did not conform to the norms of the series. ${ }^{26}$ The new edition removed all instances of Pippi's resistance to adult 
authority. For example, one chapter was removed because the heroine was depicted outwitting two lumbering policemen who are trying to take her away to a children's home. Another episode, in which a visit to school goes awry, was modified to add in an apology underscoring the importance of the family in socialising the child: "I am insufferable, but, you know, when you live on your own, you end up becoming a little different to everyone else." ${ }^{27}$ As Christina Heldner notes, Pippi was a critique of institutions such as school whereby adults seek to repress children's natural vivacity; it was a defence of children's rights (Heldner 1992: 65-71). In other words, Pippi was a joyous rejection of all the values that France craved to return to in the wake of the Second World War, and ran counter to the discourse on the responsibilities of literature. In striking contrast, Pippi was welcomed into the American and British literary systems. Where the French discourse was suspicious of fantasy, Eva-Maria Metcalf has shown that Pippi was accepted in the United States precisely because she could be "labelled as nonsense or fantasy, [thus] Pippi's outrageous behaviour was not thought to present much moral danger to readers who, it was assumed, would scarcely try to identify with or imitate Pippi" (Metcalf 2011: 18). The first British edition from 1954 embraced, even amplified, her anarchism. The front cover illustration by Richard Kennedy depicted Pippi on horseback brandishing a pistol, riding away from school leading a group of children to escape school as the teacher looks on, horrified.

\section{Enid Blyton and the "Anglo-Saxon" Other}

This difference between the French and British editions of Pippi is not surprising. As Lucy Pearson has shown, the postwar period witnessed a "golden age" of British children's literature, characterised by "an emphasis on children as imaginative, autonomous and complex beings" (Pearson 2013: 34). However, the extent to which the French and British understandings of what was appropriate reading matter for children could differ is best understood by looking not at the innovators, but at the case of Enid Blyton, the most conservative of British authors and who wrote for the mass market. Given that she was also a passionate spokesperson for the British campaign against horror comics (Lent 2009: 74), one could be forgiven for assuming that her books would pose no moral problems in France. However, she fell foul of the dictum that parental authority must be upheld. Blyton had trained as a Froebel teacher, and believed passionately that freedom to explore and enjoy autonomy was crucial to children's development. She relegated her adult characters to the background, and her young protagonists often ridiculed adults for seeking to interfere in their activities (Rudd 2000: 97-102). The deliberations over the manuscript translation of Blyton's Five Get into a Fix (1958), Le Club des cinq aux sports d'hiver (1964) provide a good example of how Blyton's ethos could clash with Hachette's norms. ${ }^{28}$ The readers objected to the children's independence from all adult supervision while they are staying at the winter chalet, and one suggested that the book explain that they were being looked after nevertheless:

it would have been preferable if the author or the farmer had, from the outset, explained that the children are living there independently, and eating their meals there, under the care and watchful eye of the chalet staff. ${ }^{29}$

Blyton's representation of parents in the book was deemed immoral. Five get into a fix features a six-year-old girl, Aily, who runs wild, and whose parents do little to prevent her from playing truant. One reader suggested the mother ought to display proper 
maternal concern for the situation, and express hope that school will cure the girl "otherwise one might ask why the social services, neighbours and authorities are not doing anything, and whether the parents are happy with this situation." ${ }^{30}$ (The published version avoided such a heavy-handed solution, but did make the mother more concerned for her daughter). Similarly, when reading the translator's manuscript of Le Mystère de la roche percée, 1960 (The Rubadub Mystery, 1952) the readers asked the translator to remove disrespectful language, to soften the story of the protagonist's parents' separation, and to remove the section where the boy says he can get by without a father. ${ }^{31}$ Her books were generally well received in France, but this aspect of her work remained problematic, even after the Hachette editions of Blyton had toned down the impression of children's autonomy. The Bulletin d'analyses de livres pour enfants criticised Blyton for presenting "a world dominated by children where the adults are mere puppets," ${ }^{32}$ while Marc Soriano worried that her model of writing risked "distorting the educational relationship between children and adults in society." ${ }^{33}$ Although some British critics also noted this issue, overall they were less concerned. ${ }^{34}$

Indeed, the readers often felt that French parents were more stringent in their discipline than in British and American families. The "Anglo-Saxon" other was used to construct an ideal of the French family as well-disciplined, civilised and respectful; part of an ordered society with proper institutions that structured the family. The European stereotype of the unruly American child was a longstanding one. American children, it was suggested, living in the vast wilds of their country, were put to work earlier and granted much more autonomy by their parents, who were not interested in civilising them. As a result, they were more likely to be disobedient and discourteous to adults (Fass and Grossberg 2012: 3). In the context of the postwar concerns about children, this perceived difference could form a blockage to the reception of American texts celebrating this model of childhood (which was being threatened by urbanisation and industrialisation), for example Sterling North's 1963 Newbery medal-winning Rascal. This was a nostalgic paean to his freeroaming Wisconsin childhood. Picking up on the boy's lack of respect for his elders, one reader explained this was to be expected in a foreign text: American and British children were allowed to talk back to their parents, but this was unsuitable for the French market. ${ }^{35}$ It was also inevitable that the Hachette readers should encounter difficulties with a text that had received the Newbery medal; the awarding body, the American Library Association, deliberately recognised books that were written from a child liberationist perspective, as part of its battle against censorship (Fass and Grossberg 2012: 27).

In conclusion, the Hachette translations policy provides an example of how the intellectual climate of the postwar era could cause serious constraints in the process of cultural transfer and clash with the publisher's desire to import best-sellers from abroad, in particular from the hyper-central producers of children's literature, Britain and America. French law in the aftermath of the war leaned heavily towards a protectionist model of rights. This forged a discourse on children's reading that constructed the child as easily influenced, possessed of a potentially dangerous imagination, and needing adult supervision. This construct could lead to direct issues with imported materials from Scandinavian and Anglo-Saxon countries, where there was a growing interest for the more child-centred, liberationist approach to children's books. Even the ultra 
conservative Enid Blyton proved to be too progressive in her emphasis on freedom from adults. The case of Hachette suggests that the French preoccupation with responsibility and protection led to a rejection of the right to children's autonomy in their books. The postwar discourse on the responsibility of literature therefore had a wide and diffuse impact-the reverberations in the field of children's literature have not been fully recognized by the general historical narrative of this era, but they were particularly marked. The real expansion of experimental children's literature in France had to await the arrival of 1968, when the liberationist discourse found its voice in the form of radical publishers such as François Ruy-Vidal and Le Sourire qui mord.

\section{BIBLIOGRAPHY}

Bauland, Marc, 1997, Les Collections de romans pour la jeunesse de la Librairie Hachette (1945-1980), D.E.A. thesis, Université de Versailles-Saint-Quentin-en-Yvelines.

Crépin, Thierry, 2001, « Haro sur le gangster ! La moralisation de la presse enfantine (1934-1954), Paris, CNRS Éditions.

Crépin, Thierry and Groensteen, Thierry (eds), 1999, On tue à chaque page ! La loi de 1949 sur les publications destinées à la jeunesse, Paris, Éditions du temps.

Ewers, Hans-Heino, 1998, "La littérature moderne pour enfants," in E. Becchi and D. Julia (eds), Histoire de l'enfance en Europe, t. 2, Paris, Seuil, p. 457-84.

Fass, Paula and Grossberg, Michael (eds), 2012, Reinventing Childhood after World War II, Philadelphia, University of Pennsylvania Press.

Heldner, Christina, 1992, "Une anarchiste en camisole de force. Fifi Brindacier ou la métamorphose française de Pippi Langstrump," Revue des livres pour enfants, no. 145, p. 65-71 Jobs, Richard Ivan, 2007, Riding the New Wave: Youth and Rejuvenation after the Second World War, Stanford, Stanford University Press.

Lent, John A., 2009, "The Comics Debate internationally," in J. Heer and K. Worcester (eds), Comics Studies Reader, Jackson, University Press of Mississippi, p. 69-76.

Lottman, Herbert, 1966, “No Time for Childhood," Library Journal, no. 91, p. 5709-12.

Metcalf, Eva-Maria, 2011, "Pippi Longstocking in the United States," in B. Kümmerling-Meibauer and A. Surmatz (eds), Beyond Pippi Longstocking: Intermedial and International Aspects of Astrid Lindgren's Works, London, New York, Routledge, p. 15-34

Mistler, Jean, 1964, La Librairie Hachette de 1826 à nos jours, Paris, Hachette.

Mollier, Jean-Yves, 2014, La Mise au pas des écrivains. L'impossible mission de l'abbé Bethléem au XXe siècle, Paris, Fayard.

Pearson, Lucy, 2013, The Making of Modern Children's Literature in Britain: Publishing and Criticism in the 1960s and 70s, Farnham, Ashgate.

Piquard, Michèle, 2004, L'Édition pour la jeunesse en France de 1945 à 1980, Paris, Enssib. 
Piquard, Michèle, 2003, "La loi du 16 juillet 1949 et la production de livres et albums pour la jeunesse," La Licorne, no. 65, p. 219-35.

Poulain, Martine, 1998, “La censure," in P. Fouché (ed), L’Édition française depuis 1945, Paris, Éditions du cercle de la librairie, p. 554-93.

Ray, Sheila, 1982, The Blyton Phenomenon: the Controversy Surrounding the World's Most Successful Children's Writer, London, Deutsch.

Rudd, David, 2000, Enid Blyton and the Mystery of Children's Literature, Basingstoke, Macmillan.

Rudd, David, 2008, “The Phenomenal Success of Enid Blyton," in J. Briggs, D. Butts and

M.O. Grenby (eds), Popular Children's Literature in Britain, Aldershot, Ashgate, p. 251-70.

Sapiro, Gisèle, 1999, La Guerre des écrivains 1940-1953, Paris, Fayard.

Toury, Gideon, 2012, Descriptive Translation Studies - and Beyond, revised edition, Amsterdam, John Benjamins.

\section{Corpus}

Bonzon, Paul-Jacques, 1967, Les Six compagnons et l'Avion clandestin, Bibliothèque Verte.

Bonzon, Paul-Jacques, 1967, Le Marchand de coquillages, Bibliothèque Rose.

Compte rendu des travaux de la commission de surveillance et de contrôle des publications destinées à l'enfance et à l'adolescence au cours de l'année 1950, 1952, Melun Imprimerie Administrative.

Guérard, Françoise and Soriano, Marc, "Le point de vue des éditeurs," interviews with major French publishers, Enfance, no. 9 (1956), p. 10-51.

Hachette Juvenile Department archives, preserved at the Institut mémoires de l'édition contemporaine [IMEC], Hachette Archives:

S14C47B3 Fiches techniques/ Dossiers de mise en fabrication, 1956-70.

S14C15B2 Comptes rendus de lecture/ Notices Bibliothèque Rose, 1945-79.

S14C48B1 Fiches techniques, notices de publication: R. Guillot, 1958-67.

S14 C36 B6 Dossiers de mise en fabrication.

S14 C162B1 Tapuscrits Princesse de Couricoura et Tarzan.

S14C32B6 Fiches techniques 1955 to 1971.

S14C27B4 Blyton, 1955-68.

S14 C30 B4 Fiche techniques pour publication, 1955-65.

S14 C36 B2 Dossiers de mise en fabrication, 1959-68.

Lindgren, Astrid, 1954, Pippi Longstocking, translated by Edna Hurup, Oxford, Oxford University Press.

Monod, Gustave, "Éditorial," Pour l'enfance. Revue du mouvement national pour la défense de l'enfance, January 1954.

Moray Williams, Ursula, 1964, Johnnie Tigerskin, Londres, George Harrap.

Soriano, Marc, 1965, "Les thèmes de la littérature de jeunesse en France depuis la $2^{\mathrm{e}}$ guerre mondiale," BBF, no. 1, p. 1-10, [En ligne], http://bbf.enssib.fr/consulter/bbf-1965-01-0001-001, consulted 22 March 2011.

Soriano, Marc, 1966, “Adapter Jules Verne," L’Arc, no. 29, p. 86-91. 


\section{NOTES}

1. "Il ne convient guère à 'notre' jeunesse." All translations are my own unless indicated otherwise.

2. "Penser l'avenir, c'est penser le sort des enfants et de la jeunesse."

3. On the religious and communist leagues, see Crépin (2001: 195-210).

4. On use of the law against pornography: Poulain (1998). Michèle Piquard's article on children's books is an important exception: Piquard (2003).

5. "La loi de 1949 s'inscrivait dans un cadre si exceptionnellement large qu'il ne faut pas d'abord la lire comme [...] une histoire de la simple et banale censure. La jeunesse avait droit, croyait-on très fermement, à la plus stricte protection nationale, pour des raisons patriotiques dramatiquement héritées, pour préserver un avenir plus heureux." ("L'ardent contexte," Crépin and Groensteen 1999: 70; also Jobs 2007: 233).

6. "Même s'ils ne se proposent qu'un but récréatif, ils [publishers] interviennent dans l'éducation de leurs jeunes lecteurs. Ils partagent les responsabilités éducatives avec la famille, l'école, la profession, le cinéma et la presse d'information." Reproduced in Compte rendu des travaux de la commission de surveillance et de contrôle des publications destinées à l'enfance et à l'adolescence au cours de l'année 1950, Melun, Imprimerie Administrative, 1952.

7. "Loi du 16 juillet 1949," p. 227.

8. Preserved at the Institut mémoires de l'édition contemporaine. All subsequent archive references refer to this fonds.

9. "Nos gros tirages ont un revers, ils nous limitent à des valeurs sûres." Quoted in Marc Soriano and Françoise Guérard (1956: 39-40).

10. "Présent[er] sous un jour favorable le banditisme, le mensonge, le vol, la paresse, la lâcheté, la haine, la débauche ou tous actes qualifiés crimes ou délits."

11. "Il vit ce qu'il lit."

12. Soriano 1965: http://bbf.enssib.fr/consulter/bbf-1965-01-0001-001.

13. "Un voile pudique." S14C47B3 Paul-Jacques Bonzon, Les Six compagnons et l'Avion clandestin, Bibliothèque Verte, 1967.

14. “M. Mirman m'a dit: il y a des conditions. Il faut modifier votre texte: je ne veux pas d'assassinat, pas de sang, les méchants doivent s'exprimer de manière châtiée sans dire de gros mots." (Chaulet 2011: 52).

15. "Le jeune lecteur est habitué à voir des bandits ou des escrocs plus bêtes que méchants et des récits assez 'roses"' (S14C47B3, Note sur la forme, Bonzon, Le Marchand de coquillages, Bibliothèque Rose, 1967).

16. "Le véritable sujet de ce roman est la délinquance juvénile, sujet délicat entre tous et qui ne semble pas avoir été abordé jusqu'ici dans les collections pour les lecteurs de 10-12 ans, du moins en France." (S14C15B2, compte rendu de lecture, Walt Morey, Angry Waters, 1969).

17. "Il ne convient guère à 'notre' jeunesse."

18. S14C48B1, folder: R. Guillot, 1958-67.

19. Ibid.

20. "Le personnage de Fifi se conforme bien mal aux normes de la Bibliothèque Rose. Fifi est une menteuse du commencement à la fin des deux ouvrages. [...] Son ambition dans la vie ? 'Devenir un tout petit pirate très féroce. Et semer la mort et l'épouvante autour de moi'. Cette Fifi semble avoir une certaine parenté avec nos blousons noirs." (S14 C36 B6, folder Fifi Princesse).

21. Johnnie Tigerskin (1964: 28).

22. "Il y a cependant une chose gênante : cette petite fille qui ment comme elle respire et qui est l'héroïne du roman ; une héroïne sympathique. Est-ce un bon exemple à proposer aux enfants qui 
ne demandent qu'à laisser libre essor à leur imagination ?" (S14C32B6, folder: Johnnie peau-detigre / Johnnie Tigerskin (1964), 23 March 1966).

23. “Tout en faisant la part du rêve, du merveilleux, du fantastique et de l'aventure, éviter l'excès d'invraisemblance et les mystères déconcertants, au moins dans les présentations risquant de faire confondre le réel et l'imaginaire et de désorienter l'esprit du lecteur." (Compte rendu des travaux de la commission de surveillance et de contrôle des publications destinées a l'enfance et à l'adolescence au cours de l'année 1950).

24. "Dans la mesure où la nature du récit ne l'exclut pas, introduire des personnages relevant d'un milieu familial, professionnel, social." (Ibid.)

25. Pippi Longstocking, translated by Edna Hurup, Oxford, Oxford University Press, 1954, p. 3.

26. For the deliberations, see S14 C36 B6, folder Fifi Princesse.

27. "Je suis insupportable, mais, tu sais, quand on vit toujours tout seul, on finit par être pas comme tout le monde." (S14 C162B1, Princesse de Couricoura typescript with corrections).

28. S14C27B4 (1955-68) Blyton, folder: Five Get into a Fix / Le club des cinq aux sports d'hiver.

29. "Il aurait été préférable que dès le début l'auteur - ou la fermière - explique que les enfants y vivent indépendants, y prennent leurs repas, sont servis et surveillés par un personnel attaché à ce chalet."

30. "Sinon on se demanderait ce que font l'assistante sociale, les voisins et les autorités, si les parents s'accommodent de cette situation."

31. S14 C30B4, folder: Le Mystère de la roche percée / The Rubadub Mystery 28/7/60 (Rose).

32. "Un monde d'enfants qui font la loi en face des adultes fantoches" (September 1969).

33. "Fausser le rapport éducatif enfant-adulte tel que la société nous le présente" (Soriano 1965).

34. On Blyton's critical fortunes in Britain, see Ray (1982).

35. S14 C36 B2, second reader's report on Little Rascal. Little Rascal was the condensed version for younger children-the unabridged edition had already been rejected.

\section{ABSTRACTS}

This paper looks at the blockages to the publication of children's literature caused by the intellectual climate of the postwar era, through a case study of the editorial policy of Hachette, the largest publisher for children at this time. This period witnessed heightened tensions surrounding the social and humanitarian responsibilities of literature. Writers were blamed for having created a culture of defeatism, and collaborationist authors were punished harshly in the purges. In the case of children's literature, the discourse on responsibility was made more urgent by the assumption that children were easily influenced by their reading material, and by the centrality of the young to the discourse on the moral reconstruction of France. As the politician and education reformer Gustave Monod put it: "penser l'avenir, c'est penser le sort des enfants et de la jeunesse." These concerns led to the expansion of associations and publications dedicated to protecting children and promoting "good" reading matter for them, and, famously, to the 1949 law regulating publications for children, which banned the depiction of crime, debauchery and violence that might demoralise young readers. Using the testimonials of former employees, along with readers' reports and editorial correspondence preserved in the Hachette archives, this paper will examine how individual editorial decisions and self-censorship strategies were shaped 
by the 1949 law with its attendant discourse of moral panic on children's reading, and how national concerns for future citizens were balanced with commercial imperatives.

Cet article examine les obstacles à la publication de la littérature jeunesse pendant la période de l'après Seconde Guerre mondiale. Ces obstacles, dus au climat intellectuel de l'époque, sont explorés à travers le cas de la politique éditoriale de Hachette, alors le plus gros éditeur de littérature jeunesse. L'après-guerre a vu une augmentation des tensions au sujet du rôle social et humanitaire de la littérature. On a accusé certains écrivains d'entretenir une culture de la défaite et les auteurs "collabos" ont été punis pendant les purges. Le cas de la littérature jeunesse apparaissait d'autant plus préoccupant que l'on pensait que les enfants étaient aisément influencés par leurs lectures, et que, dans le discours de reconstruction morale du pays, la jeunesse occupait une place centrale. C'est bien ce que voulait dire Gustave Monod, homme politique et réformateur en matière d'éducation, lorsqu'il déclarait que "penser l'avenir, c'est penser le sort des enfants et de la jeunesse». Ceci eut pour conséquence une prolifération d'associations et de publications visant à protéger les enfants et à promouvoir de «bonnes lectures ». En découla également la célèbre loi de 1949 qui règlementait les publications destinées à la jeunesse. La loi interdisait toute description de crime, de débauche ou de violence qui soit de nature à démoraliser les jeunes lecteurs. Cet article se base sur des témoignages d'anciens employés de Hachette, sur des rapports de lecture et des correspondances conservées dans les archives de l'éditeur, et analyse la manière dont la loi de 1949, avec son discours empreint de crainte morale, a pesé sur les décisions éditoriales individuelles et les stratégies d'auto-censure. L'article analyse également le difficile équilibre entre les préoccupations nationales pour les citoyens en devenir et les impératifs commerciaux.

INDEX

Keywords: children's literature, Hachette, Bibliothèque rose, 1949 law, self-censorship

Mots-clés: littérature pour la jeunesse, Hachette, Bibliothèque rose, loi de 1949, auto-censure

\section{AUTHOR}

\section{SOPHIE HEYWOOD}

University of Reading (UK), Department of Modern Languages and European Studies 